\title{
MONITORING OF OCCUPATIONAL EXPOSURE TO NITROUS OXIDE
}

\author{
S. Mehta, P. Burton, AND J.S. SIMMS
}

DESPITE THE CONTINUING CONTROVERSY about the potential hazards to operating theatre personnel of chronic exposure to low concentrations of anaesthetic gases and vapours, there is no satisfactory evidence about the relation between the concentrations in the theatre environment and the real exposures of the persons working in such environment.

Basically three methods have been described to determine individual exposure to inhaled anaesthetics. (1) Periodic or multiple spot sampling. Air samples from the breathing zone are obtained in glass syringes. As early as 1969 Lind and Bruce' ${ }^{1}$ used this method to determine the exposure of anaesthetists. They reported nitrous oxide concentration to average $130 \mathrm{ppm}$ with peak levels as high as $\mathbf{4 2 8} \mathrm{ppm}$ in the vicinity of the anaesthetist. (2) Continuous sampling or integrated personal sampling. This can be achieved by a portable infrared monitoring unit, battery operated pump and gas tight bags as described by Whitcher and his colleages ${ }^{2}$ or Wright's bottle as described by Davenport and his colleagues, ${ }^{3}$ which is carried on the person taking samples from the breathing zone. (3) Blood samples and end-tidal sampling. Nikki, et al. ${ }^{4}$ measured the concentration of nitrous oxide in the end-tidal air and the concentration of halothane in venous blood to confirm the efficacy of scavenging systems. Cole ${ }^{5}$ suggested that only blood samples will provide a simple and reliable measure of the average exposure, integrated over time. However, since nitrous oxide is a relatively insoluble agent, equilibrium between the tension in the alveolus and most tissues including blood is achieved fairly rapidly. End-tidal samples can provide adequate information and, furthermore, these are much simpler and easier to obtain from theatre personnel than repeated blood samples. ${ }^{6}$

This study was undertaken to evaluate these three methods of measuring occupational exposure to nitrous oxide in an operating theatre which had no ventilation system and to investigate the effect of passive scavenging.

S. Mehta, M.B., B.S., F.F.A.R.C.S., Consultant Anaesthetist, P. Burton, B.Sc., M.C.B., Biochemist, J.S. Simms, M.R.I.C., Biochemist, Bumley General Hospital, Burnley, Lancs., BB10 2PQ, England.

Canad. Anaesth. Soc. J., vol. 25, no. 5, September 1978

\section{METHODS}

Spot sampling

Spot samples were taken from three points. (1) The breathing zone of the anae sthetist $60 \mathrm{~cm}$ from the Heidbrink valve in the anaesthetic room and in the operating room. (2) The periphery of the operating room about 1.8 metres from the operating table. Both these samples were taken at the height of 1.5 metres from the floor level. (3) At floor level near the anaesthetic machine. These samples were obtained 10 minutes after induction in the anaesthetic room and after 10 minutes of anaesthesia in the operating room. Air samples were collected from the operating room before the operating session.

Air was sampled by slow withdrawal into a clean tight-fitting $10 \mathrm{ml}$ glass syringe with a nylon tap.

\section{Integrated personal sampling}

This method has been described by Davenport and his colleagues. ${ }^{3}$ Samples were collected in $250 \mathrm{ml}$ glass bottles fitted with stoppers containing a spring loaded valve. A simple vacuum regulator was screwed into the stopper and a vacuum of about 0.9 atmosphere was created so that constant flow could be obtained until pressure in the bottle rose to atmospheric pressure. The regulator was fitted with a needle valve with which the rate of flow was adjusted to $15 \mathrm{ml} / \mathrm{min}$.

The subject carried the bottle in a pocket and a length of $1 \mathrm{~mm}$ nylon tubing was fitted with its open end attached to the outside of the face mask. Sampling was started by screwing in the regulator at the beginning of exposure and stopped at the end by unscrewing it.

\section{End-tidal sampling}

End-tidal samples were obtained from anaesthetist, scrub-nurse and the circulating nurse after approximately three hours of exposure. They were instructed to exhale about two-thirds and then breathe into a rubber bag. Ten $\mathrm{ml}$ of this expired air was drawn into a glass syringe for analysis. Ten breath-decay curves for nitrous oxide were determined in anaesthetists following routine three-hour exposures in the operating room. 
Anaesthetic technique - The anaesthetic method and the agents were controlled rigorously during spot sampling and integrated personal sampling. Tracheal intubation in all patients was with a cuffed tube. A Magill breathing circuit was used and fresh gas flow of nine litres $\left(\mathrm{N}_{2} \mathrm{O} 6\right.$ litres and $\mathrm{O}_{2} 3$ litres) was employed. All patients were allowed to breathe spontaneously. Spot sampling and integrated personal sampling were carried out at the beginning of the operating session.

Waste gas scavenging system - This consisted of a waste gas collector valve (MIE expiratory valve with a swivelling gas tight hood) a pressure balancing device, and a passive disposal system. ${ }^{\text {? }}$

Analysis - At the end of the sampling period clean air was allowed to enter the bottles from an all glass matched barrel syringe. The volume of air entering the bottle was noted and from the known volume of the bottle, the dilution factor was calculated.

The measurement of nitrous oxide concentration was carried out on a Pye 104 Gas chromatograph fitted with a $63 \mathrm{Ni}$ electron capture device. The detector was held at $250^{\circ} \mathrm{C}$ and $150 \mu \mathrm{S}$ pulse space. Prior separation was achieved on a $1.5 \mathrm{~m}$ $\times 4 \mathrm{~mm}$ glass column held at $80^{\circ} \mathrm{C}$ and filled with $80 / 100$ mesh Porapak Q. The carrier gas was nitrogen at $40 \mathrm{ml} / \mathrm{min}$ and the sample loop volume was $1.0 \mathrm{ml}$.

The standards were obtained by volume dilution of medical-grade nitrous oxide. Nitrous oxide concentration from $5-2000 \mathrm{ppm}$ could be measured by the use of the attentuator on the gas chromatograph. A sample containing higher concentration than $2000 \mathrm{ppm}$ was further diluted and re-measured. The values obtained were then corrected for any dilution before analysis. Each sample was analyzed in duplicate.

\section{RESUlTS AND Discussion}

The escape of waste anaesthetic gases from the anaesthetic circuit at the time when measurements were made was standardized by using identical anaesthetic circuits with the same fresh gas flow. Nitrous oxide is the most important anaesthetic in monitoring of occupational exposure of theatre personnel because it is the most widely used. By measuring nitrous oxide concentrations in different parts of the operating suite the pattern of spread of nitrous oxide was demonstrated.

Table I shows the results of spot sampling when no precautions are taken and after the use of passive scavenging. The concentration of ni- trous oxide in both the anaesthetic room and the operating room increased immediately after the beginning of anaesthesia. It was found that nitrous oxide is not distributed uniformly throughout the operating room. The unequal distribution of anaesthetic gas is more likely to occur in rooms which are not ventilated. Variation in anaesthetic concentration in the operating room environment depends on various factors such as site and rate of gas leakage, the movement of personnel, the location of equipment, surgical drapes, opening and closing of doors. The concentration of nitrous oxide varied greatly and the range was very wide. This may be due to disturbances of the normal flow patterns of the air in the region of sampling. Robinson and his colleagues ${ }^{8}$ have recently described a continuously operating automatic air sampling device which ensures minimal disturbance of the normal flow patterns of the air in the region of sampling. The time period over which an air sample is obtained is also very important. Unless the air is thoroughly mixed, an air sample from a single rapidly filled syringe may not be representative. This problem can be largely overcome by drawing air slowly at a constant rate and by taking multiple samples. However, the results show that the anaesthetist's exposure in the anaesthetic room can be much higher and in the operating room the exposure was reduced over three-fold by passive scavenging.

Table II shows the results of integrated personal sampling during the exposure of personnel over a 10-minute period. It shows clearly that the anaesthetist's exposure in the anaesthetic room is much higher. Without the use of scavenging the mean exposure of both the anaesthetist and the scrub nurse in the operating room was identical and the exposure of the circulating nurse was lower. It is evident that gas concentrations measured around one person do not necessarily parallel the concentration present near others. Scavenging produced nearly a five-fold reduction in exposure of all personnel in the operating room. . The main advantage of integrated personal sampling is that it gives a simple and reliable measure of the average exposure of the person integrated over time. There is a considerable saying of time and labour compared with taking and analyzing multiple spot samples.

Table III shows the results of end-tidal sampling in personnel after three hours of exposure in the operating room. The results show that the mean exposure of anaesthetist and scrub nurse was similar while the circulating nurse's expo- 
TABLE I

Multiple Spot Sampling: Exposure of Operating Room Personnel Over 10-Minute Period. Magil.t Circuit and Spontaneolns Respiration $\left(\mathrm{N}_{2} \mathrm{O}: \mathrm{O}_{2} 6: 3 \mathrm{I} / \mathrm{MIN}\right)$ (Results are means (and ranges) of nitrous oxide (ppm))

\begin{tabular}{|c|c|c|c|c|}
\hline . & $\begin{array}{c}\text { Anaesthetist's breathing } \\
\text { zone in the induction } \\
\text { room }\end{array}$ & $\begin{array}{l}\text { Anaesthetist's breathing } \\
\text { zone in theatre }\end{array}$ & $\begin{array}{l}\text { Periphery of } \\
\text { the theatre }\end{array}$ & $\begin{array}{c}\text { Floor level } \\
\text { near } \\
\text { the anaesthetic } \\
\text { machine }\end{array}$ \\
\hline \multicolumn{5}{|l|}{ No precautions } \\
\hline $\begin{array}{l}\text { Number of samples } \\
\text { Mean (and ranges) }\end{array}$ & $\begin{array}{c}15 \\
1015.33 \\
(100-4000)\end{array}$ & $\begin{array}{c}15 \\
871.73 \\
(35-1870)\end{array}$ & $\begin{array}{c}15 \\
586.33 \\
(210-1020)\end{array}$ & $\begin{array}{c}15 \\
1581.5 \\
(55-3440)\end{array}$ \\
\hline $\begin{array}{l}\text { Passive scavenging } \\
\text { Number of samples } \\
\text { Mean (and ranges) }\end{array}$ & & $\begin{array}{c}15 \\
245.85 \\
(22-680)\end{array}$ & $\begin{array}{c}15 \\
256.6 \\
(30-870)\end{array}$ & $\begin{array}{c}15 \\
665.8 \\
(22-1200)\end{array}$ \\
\hline
\end{tabular}

TABLE II

Integrated Personal Sampling: Exposure of Operating Room Personnel Over 10-Minute Period. Magill Circuit and Spontaneous Respiration $\left(\mathrm{N}_{2} \mathrm{O}: \mathrm{O}_{2} 6: 3 \mathrm{l} / \mathrm{MIN}\right)$ (Results are means (and ranges) of nitrous oxide (ppm))

\begin{tabular}{lcccc}
\hline \hline & $\begin{array}{c}\text { Anaesthetist in } \\
\text { induction room }\end{array}$ & $\begin{array}{c}\text { Anaesthetist } \\
\text { in theatre }\end{array}$ & Scrub nurse & $\begin{array}{c}\text { Circulating } \\
\text { nurse }\end{array}$ \\
\hline $\begin{array}{l}\text { No precautions } \\
\text { Number of samples }\end{array}$ & 15 & 15 & 15 & 15 \\
Mean (and ranges) & 1829.13 & 1201.26 & 1229.1 & 1062.53 \\
Passive scavenging & $(986-2775)$ & $(583-1932)$ & $(760-1908)$ & $(875-1534)$ \\
Number of samples & & 15 & 14 & 15 \\
Mean (and ranges) & & 273.9 & 265.4 & 258.7 \\
& & $(54-535)$ & $(46-622)$ & $(40-651)$ \\
\hline
\end{tabular}

TABLE IIT

End-Tidal Sampling. Exposure of Operating Room Personnel Over Three-Hour Operating Session (Results are mean and ranges of nitrous oxide (ppm))

\begin{tabular}{lccc}
\hline & Anaesthetist & Scrub nurse & $\begin{array}{c}\text { Circulating } \\
\text { nurse }\end{array}$ \\
\hline $\begin{array}{l}\text { No precautions } \\
\text { Number of samples }\end{array}$ & 13 & 14 & 13 \\
Mean (and ranges) & 958.84 & 906.07 & 781.53 \\
Passive scavenging & $(200-2040)$ & $(70-1900)$ & $(50-2120)$ \\
Number of samples & 13 & 13 & 13 \\
Mean (and ranges) & 196.69 & 141.07 & 241.9 \\
& $(<5-440)$ & $(<5-440)$ & $(8-740)$ \\
\hline
\end{tabular}

sure was lower. The scavenging of expired anaesthetic gas led to about a five-fold reduction in exposure of anaesthetist, six-fold reduction in exposure of scrub nurse and three-fold reduction in exposure of the circulating nurse. Although end-tidal samples are easier to obtain from operating room personnel and can provide adequate information regarding occupational exposure to nitrous oxide, the main disadvantage of the end-tidal sampling is that, because nitrous oxide is so rapidly absorbed and excreted, it reflects the most recent exposure of the subject. To obtain meaningful data on average exposure integrated over time one needs to take a number of 
TABLE IY

Pre-Exposure levels of Nitrous Oxide (PPM) in Operating Room Personnel. End-Tidal Sampling

\begin{tabular}{|c|c|c|c|}
\hline & Anaesthetist & Scrub nurse & $\begin{array}{c}\text { Circulating } \\
\text { nurse }\end{array}$ \\
\hline $\begin{array}{l}\text { Number of samples } \\
\text { Mean } \\
\text { Range }\end{array}$ & $\begin{array}{c}28 \\
19.6 \\
(<5-68)\end{array}$ & $\begin{array}{c}26 \\
24.6 \\
(<5-170)\end{array}$ & $\begin{array}{c}27 \\
28.5 \\
(<5-140)\end{array}$ \\
\hline
\end{tabular}

end-tidal samples. Breath decay curves show that the concentration of nitrous oxide was below 5 ppm in end-tidal samples one hour after the end of exposure.

Table IV shows pre-exposure levels of nitrous oxide in the end-tidal samples obtained from operating room personnel. In an unventilated operating room trace concentrations of nitrous oxide were still present 12 to 18 hours after the end of the operating session. The mean concentration of nitrous oxide found before the operating session was $40.53 \mathrm{ppm}$. Since the preexposure end-tidal samples were obtained from the personnel in the operating suite, they had in fact already been exposed to a stagnant atmosphere of nitrous oxide.

It is evident from the study that all three methods described, i.e. multiple spot sampling, integrated personal sampling, and end-tidal sampling can yield representative time-weighted exposure patterns. However, the integrated personal sampling is considered the preferable method as it involves considerable saving of time and labour compared with taking and analysing multiple end-tidal and spot samples. The wide variation in levels of nitrous oxide found in the theatre could be explained by absence of aisconditioning system or ventilation and by the fact that certain activities such as movement of personnel, location of equipment and furniture, use of surgical drapes, opening and closing of doors, cannot be easily controlled.

Although the safe levels of air contamination by inhalational anaesthetic agents are not known, it is suggested that under favourable conditions the achievable concentrations during the routine use of inhalational agents are $30 \mathrm{ppm}$ of nitrous oxide and $0.5 \mathrm{ppm}$ of halothane. ${ }^{2}$ It is quite evident from this study that these concentrations cannot be achieved by the use of waste gas scavenging systems alone. Thus one ought to consider careful application of other measures such as the use of an efficient ventilation system, regular equipment maintenance, careful anaes- thetic techniques to prevent gas leaks and an air monitoring programme to indicate the effectiveness of these measures. ${ }^{6}$ Failure to institute any of these measures will continue to lead to exces. sive exposure of the operating room personnel to anaesthetic gases and vapours.

\section{SUMmarY}

The occupational exposure of operating room personnel to nitrous oxide was investigated by using multiple spot sampling, integrated personal sampling and end-tidal sampling in an operating room which had no ventilation system. The effect of passive scavenging on occupational exposure was determined. The study showed that all three methods to determine occupational exposure can yield representative time-weighted exposure patterns. However, the integrated personal sampling was considered the preferable method as it involved considerable saving of time and labour compared with taking and analyzing multiple end-tidal and spot samples.

Passive scavenging of waste anaesthetic gases led to a three-fold to six-fold reduction of exposure of operating room personnel to nitrous oxide.

\section{RÉSUMÉ}

Les effets de l'exposition au protoxyde d'azote chez le personnel d'une salle d'opération ont été étudiés suivant trois techniques différentes, à savoir: (1) une série d'échantillons pris à des endroits et des moments prédéterminés, (2) une aspiration continue dans une bouteille de $250 \mathrm{ml}$ portée par un membre du personnel (ẻchantillonnage intégré), et enfin (3) au moyen d'échantillons prélevés en fin d'expiration, tout ceci dans des salles non protégées par un système de vidange des vapeurs anesthésiques. L'efficacité d'un système de vidange passif des anesthésiques a également été êvaluée.

L'étude a montré que les trois méthodes permettent d'évaluer efficacement les effets de l'exposition aux vapeurs anesthésiques. L’échantil- 
lonnage personnel intégré semble préférable car celte méthode est plus simple et plus rapide que les deux autres. La vidange passive des vapeurs anesthésiques permet une diminution de trois à six fois du taux d'exposition au protoxyde d'azote chez le personnel de la salle d'opération.

\section{ACKNOWLEDGEMENTS}

The authors are grateful to Dr. H. T. Davenport for the supply of Wright's bottles and helpful advice.

The authors would also like to thank the nursing staff of the operating room, Hartley Hospital, Colne for their co-operation, Mr. P.C. Callaghan, theatre technician for technical assistance and Mrs. M. Lambert for secretarial help.

\section{REFERENCES}

1. LINDE, H.W. \& BRUCE, D.L. Occupational exposure of anaesthetists to halothane, nitrous oxide and radiation. Anesthesiology 30:363 (1969).
2. Whitcher, C., Pizial, R., Sher, R., \& Moffat, R.J. Development and evaluation of methods for the elimination of waste anacsthetic gases and vapours in hospitals. P. VII-9 and VIII-1, HEW publication No. (N IOSH) 75-137 (1975).

3. Davenport, H.T., Halsey, M.J., WardleySMITH, B., \& WRIGHT, B.M. Measurement and reduction of occupational exposure to inhaled anaesthetics. British Medical Journal 2: 1219 (1976).

4. NikKı, P., Pfaffli, P., \& Ahlman, K. End-tidal and blood halothane and nitrous oxide in surgical personnel. Lancet $i i: 490$ (1973).

5. Cole, P.V. Occupational exposure to inhaled anaesthetics. British Medical Journal ii: 1563 (1976).

6. Mehta, S., Burton, P., \& Simms, J.S. Occupational exposure to inhaled anaesthetics. British Medical Journal $i$ : 507 (1977).

7. Mehta, S., Behr, G., \& Kenyon, D. A passive method of disposal of expired anaesthetic gases. Brit. J. Anaesth. 49:589 (1977).

8. Rohinson, J.S., Thompson, J.M., Barrett, R.S., Belcher, R., \& StePhen, W.I. Pertinence and precision in pollution measurement. Brit. J. Anaesth. 48: 167(1976). 